\title{
Stage II Breast Cancer AJCC v6 and v7
}

National Cancer Institute

\section{Source}

National Cancer Institute. Stage /I Breast Cancer A/CC v6 and v7. NCI Thesaurus. Code C7768.

Stage II includes: IIA: (T0, N1, M0); (T1, N1, M0); (T2, N0, M0) and IIB: (T2, N1, M0); (T3, N0, M0). T0: No evidence of primary tumor. T1: T umor $2.0 \mathrm{~cm}$ or less in greatest dimension. T1 includes T1 mi. T1 mi: Tumor $1 \mathrm{~mm}$ or less in greatest dimension. T2: Tumor more than $2.0 \mathrm{~cm}$ but not more than $5.0 \mathrm{~cm}$ in greatest dimension. T3: Tumor more than $5.0 \mathrm{~cm}$ in greatest dimension. N1: Metastasis to movable ipsilateral axillary lymph node(s). M0: No distant metastasis. (AJCC 6th and 7th Eds.) 